\title{
Palavras e pílulas: \\ SOBRE O GOVERNO DO MAL-ESTAR NA \\ ATUALIDADE
}

Bárbara Paraiso Garcia Duarte da Rosa

O objetivo do presente trabalho é analisar a condução do mal-estar na atualidade. O mal em questão é o sofrimento psíquico. Abordaremos o governo do malestar na atualidade do campo psiquiátrico, mais especificamente de certo discurso sobre as pílulas, o discurso da psiquiatria biológica - voltado para a regulação de quase todo e qualquer mal-estar psíquico. Investigaremos também a condução do mal contida em algumas das produções freudianas, levando em consideração a elaboração de certos conceitos, culminando no conceito de pulsão de morte.

\section{BANCA:}

Monah Winograd (Orientadora)

Carlos Augusto Peixoto Junior

Jurandir Sebastião Freire Costa

Data da defesa: 22/01/2010 